\title{
Service Quality of CRM: With Reference to Public and Private Banks in Nagpur City
}

\author{
Gangu Naidu Mandala ${ }^{1, *}$, Meenakshi Verma ${ }^{1}$, Anuj Verma ${ }^{1}$, Pushpanatham Arumugam $^{2}$ \\ ${ }^{1}$ Symbiosis Institute of Business Management, Symbiosis International Deemed to be University, Nagpur, India \\ ${ }^{2}$ Department of Human Resource Management, Dwaraka Doss Goverdhan Doss Vaishav College, Chennai, India
}

Received January 10, 2021; Revised February 13, 2021; Accepted March 23, 2021

\begin{abstract}
Cite This Paper in the following Citation Styles
(a): [1] Gangu Naidu Mandala, Meenakshi Verma, Anuj Verma, Pushpanatham Arumugam, "Service Quality of CRM: With Reference to Public and Private Banks in Nagpur City," Universal Journal of Accounting and Finance, Vol. 9, No. 2, pp. 191 - 196, 2021. DOI: 10.13189/ujaf.2021.090207.
\end{abstract}

(b): Gangu Naidu Mandala, Meenakshi Verma, Anuj Verma, Pushpanatham Arumugam (2021). Service Quality of CRM: With Reference to Public and Private Banks in Nagpur City. Universal Journal of Accounting and Finance, 9(2), 191 196. DOI: 10.13189/ujaf.2021.090207.

Copyright $\odot 2021$ by authors, all rights reserved. Authors agree that this article remains permanently open access under the terms of the Creative Commons Attribution License 4.0 International License

Abstract Purpose: The banking business is significant for each country yet with the extreme rivalry between the public and private area banks, it is the service given that surprisingly recognizes the banks. The bank's execution relies upon how they fulfill and draw in their modern clients. Deals are straightforwardly identified with consumer loyalty. As the deals are expanding there is a necessity of improving the quality of services they conveyed. The item is utilized by the client and the abundance expansion is relying upon their fulfillment level. Design/methodology/approach: The examination broke down the public and private area bank clients' conclusions on CRM concerning service quality and furthermore analyzed their assessment on it. The examination likewise attempts to establish the general correlation of the clients' insight. For the investigation, 240 clients were chosen as a respondent from public and private area banks. Findings: The examination found the view of clients and attempts to advise the path to the banks that how they can hold the old ones and pull in the new ones (clients). Originality/value: The examination demonstrated that in the assessment of public bank clients they scarcely have service quality in their bank and the private bank clients indicated that their bank has better service quality. It very well may be deciphered that in the event that there is an absence of service quality, at that point long-haul relationship with the client may influence. It is inferred that banks need to reinforce their services to satisfy their prerequisites to profit the advantage over the long haul.
Keywords Competitive Advantage, Commercial Banks, Quality, Customer Relations, Competitive Strategy

JEL Classification: M1, G2, G4, M5

\section{Introduction}

Retail banking in India has quickly emerged as one of the first drivers of the total banking industry and has seen enormous development in the new past. Khatab, J.J., Esmaeel, E.S., Othman, B [1] The Retail Banking Report incorporates wide-going examination and investigation of this quickly developing area. It chiefly covers examination of the current status, latest things, central questions, and difficulties in the development of the retail banking area. Sharma, R., Mittal, A., Bagga, T [2] This report helps Banks, monetary organizations, MNC Banks, academicians, advisors, and specialists to have a piece of superior information on the thriving breaks in retail banking in India.

Ammara Noreen, Rabia Asif, Sabahat Nisar, Noman Qayyum [3] Banks in India have begun the British example at the start of the nineteenth century. Choudhury, K., [4] In the main portion of the nineteenth century, The East India Company set up 3 banks: The Bank of Bengal, The Bank of Bombay, and The Bank of Madras. These three banks were considered as administration banks. These three banks in 1920 were combined and the 
Imperial bank of India was shaped. At that period, all the banks were joint-stock banks and the greater part of the banks were minor and feeble. What's more, in the time of 2 and world battle in India around 1500 joint-stock banks were working and out of those, the greater part of them were non-booked banks. Ogilo Fredrick, Omwoyo Jeremiah, Zipporah Onsomu [4] In view of untrustworthy just as terrible administration, there were a number of bank disappointments. Accordingly, the public authority needed to venture into the banking organization's demonstration, which prompted the expulsion of the little just as powerless banks that were not in the situation to stand and satisfy the colossal necessities of the demonstration. To fortify their powerless units and survey public trust in the banking framework, another segment 45 was passed in the Banking Regulation Act in the year 1960, empowering the Government of India to vital amalgamate powerless units with the harder ones on the reference of the RBI. Choudhury, K [5].

Customer Perception of service: This is a promoting origination that includes client mindfulness, awareness, or impression about any banking establishment or organization and their contributions. Sujatha, J, Ananthanarayanan, N.R., Kannan, M [6] Essentially, the client view of service is regularly affected by online media, promoting, a word from the mouth of some reliable individual or and so on Client's view of service can ordinarily be apportioned into the impression of dependability, responsiveness, affirmation, sympathy, and effects. Sharma, R., Mittal, A., Bagga, T [7].

\section{Statement of the Problem}

The main role of the executives and showcasing technique is to build up an upper hand. An upper hand furnishes clients with prevalent worth contrasted and serious contributions. Banking has generally worked in a moderately steady climate for quite a long time. The motivation behind the examination is to hypothetically and exactly build up a superior comprehension of quality and client relationship the executives (CRM) sway on banking intensity.

\section{Objectives of the Study}

The principle targets of this examination is to hypothetically and observationally build up a superior comprehension of the connection between client relationship, service quality and bank key serious situating 1. To compare the opinion of customers on service quality statements of public and private sector banks.

2. Overall comparison of customer's perception on service quality

\section{Research Methodology}

This examination utilized an expressive exploration configuration to gauge the effect of service quality on CRM. The examination has been directed on 240 clients of public and private area banks in Punjab. Utilizing a defined irregular testing method, the region for research was chosen. For the examination, Nagpur city was chosen dependent on the quickly developing zone as indicated by the enumeration of Maharastra. For the exploration, the banks were chosen dependent on the most noteworthy bank offices in the locale and the eight banks are in particular SBI, PNB, PSB, OBC (public banks) and ICICI, HDFC, AXIS, Yes Bank (private banks). From each bank, 20 respondents were picked by utilizing the persuade examining. A self-organized poll with 22 things cover five elements of service quality was utilized to record the reaction of clients. The outlined poll depended on the SERVPERF. SERVPERF instrument considers by numerous analysts as a more exact proportion of the quality of service than SERVQUAL (Toloie-Eshlaghy, , Ghafelehbashi, , Alaghebandha, M [8] ). Clients were approached to offer their input with respect to their banks' CRM works on keeping in view the parts of service quality. A pilot overview was led to 40 clients. For checking the unwavering quality of the assertions, the estimation of Cronbach's alpha has been registered and discovered to be satisfactory (for example 0.795 utilizing SPSS 21). Factual instruments, for example, illustrative insights, theory testing utilizing one example t-measurements, and autonomous t-insights used to dissect the information. All the five aspects of service quality are assessed using five-point Likert scales where 1-5 denote the following: 1 for strongly disagree to 5 for strongly agree. 
Table 1. Analysis and Interpretation

\begin{tabular}{|c|c|c|c|}
\hline Demographic profile & & Frequency & Percentage \\
\hline \multirow{3}{*}{ Gender } & Male & 141 & 58.75 \\
\hline & Female & 99 & 41.25 \\
\hline & Total & 240 & 100 \\
\hline \multirow{3}{*}{ Marital Status } & Married & 156 & 65 \\
\hline & Unmarried & 84 & 35 \\
\hline & Total & 240 & 100 \\
\hline \multirow{7}{*}{ Age } & $15-25$ & 46 & 19.16 \\
\hline & $26-35$ & 84 & 35 \\
\hline & $36-45$ & 60 & 25 \\
\hline & $46-55$ & 24 & 10 \\
\hline & $56-65$ & 10 & 4.16 \\
\hline & 65 and Above & 16 & 6.66 \\
\hline & Total & 240 & 100 \\
\hline \multirow{8}{*}{ Educational Status } & Illiterate & 8 & 3.33 \\
\hline & High School & 29 & 12.08 \\
\hline & Graduation & 72 & 30 \\
\hline & Diploma & 26 & 10.83 \\
\hline & Post-Graduation & 64 & 26.66 \\
\hline & Professional Course & 35 & 14.53 \\
\hline & Other & 6 & 2.5 \\
\hline & Total & 240 & 100 \\
\hline \multirow{8}{*}{ Occupation } & Student & 22 & 9.16 \\
\hline & Govt. Employee & 13 & 5.41 \\
\hline & Retired & 9 & 3.75 \\
\hline & Business/Professional & 116 & 48.33 \\
\hline & House Wife & 34 & 14.16 \\
\hline & Farmer & 39 & 16.25 \\
\hline & Other & 7 & 2.91 \\
\hline & Total & 240 & 100 \\
\hline \multirow{8}{*}{ Monthly Income } & Below 25000 & 52 & 21.66 \\
\hline & $25000-35000$ & 68 & 28.33 \\
\hline & $35000-45000$ & 46 & 19.16 \\
\hline & $45000-55000$ & 5 & 2.08 \\
\hline & $55000-60000$ & 9 & 3.75 \\
\hline & 60000 and above & 2 & 0.83 \\
\hline & Not applicable & 58 & 24.16 \\
\hline & Total & 240 & 100 \\
\hline
\end{tabular}

Sources: Primary Data

From table no. 1, it tends to be seen that out of 240 respondents, 58.7 percent are male and 41.3 percent are females. The wedded respondent comprises 65 percent of the aggregate though 35 percent are unmarried. It is obvious from the above table that almost 19.1 percent fall in the classification of 15-25 years while 35 percent of respondents fall between 26-35 years' age gathering. 25 percent of respondents are in the age gathering of 36-45 years, $10 \%$ fall in the age gathering of $46-55$ years, 4.16 percent of 56-65 age gathering, and just 6.66 percent fall in over 65 years' age gathering. As appeared in the above table, graduation and post-graduation framed most of the example respondents with $30 \%$ and 26.66 percent individually. It is trailed by proficient course 14.53 percent and confirmation 10.83 percent individually. The secondary school and unskilled comprise 3.33 percent separately. Different respondents comprise 6 percent. It is uncovered from the table that calling/business has a dominant part of 48.3 percent of test respondents and the remaining was 9.1 percent understudy, 5.41 percent were government workers, resigned 3.75 percent, and others 2.91 percent. 16.25 percent are ranchers and 14.1 percent of respondents are housewives. The above table shows that, 21.5 percent and 29.2 percent. Respondents in the gathering of procuring under 25000 and 25000 to 35000 separately. Procuring of not material respondents is put with 24.1 percent which incorporates housewives, understudies, and jobless individuals. Those are having profit between 35000 to 45000 is 19.1 percent and 3.75 percent for 55000 to 60000 . Finally, the excess gatherings procuring having a similar rate for example 2.08 and 0.83 percent lies between 45000 to 55000 and 60000 and above. 
In the examination, the service quality is estimated banks. through 22 proclamations for both public and private area

Table 2. Comparison between the public sector and private sector banks on service quality variable

\begin{tabular}{|c|c|c|c|}
\hline Service Quality Statements & Type of Bank & T-stats. & Sig. \\
\hline \multicolumn{4}{|l|}{ Tangibility- appearance of physical facilities, equipment and personnel } \\
\hline \multirow{2}{*}{ Bank has up to date equipment } & Public Bank & \multirow{2}{*}{-1.083} & \multirow{2}{*}{.122} \\
\hline & Private Bank & & \\
\hline \multirow{2}{*}{ Bank's physical facilities are visually appealing } & Public Bank & \multirow{2}{*}{-1.002} & \multirow{2}{*}{.133} \\
\hline & Private Bank & & \\
\hline \multirow{2}{*}{ Bank's employee are well dressed and appear neat } & Public Bank & \multirow{2}{*}{-1.273} & \multirow{2}{*}{.133} \\
\hline & Private Bank & & \\
\hline \multirow{2}{*}{$\begin{array}{l}\text { The appearance of the physical facilities of bank is in keeping with the type of } \\
\text { service provided }\end{array}$} & Public Bank & \multirow{2}{*}{-1.442} & \multirow{2}{*}{$.003 *$} \\
\hline & Private Bank & & \\
\hline \multicolumn{4}{|l|}{ Reliability-ability to perform the promised service accurately and dependably } \\
\hline \multirow{2}{*}{ Bank is dependable } & Public Bank & \multirow{2}{*}{-1.410} & \multirow{2}{*}{$.006^{*}$} \\
\hline & Private Bank & & \\
\hline \multirow{2}{*}{ Bank provides its services at the time it promise to do so } & Public Bank & \multirow{2}{*}{-1.214} & \multirow{2}{*}{.175} \\
\hline & Private Bank & & \\
\hline \multirow{2}{*}{ When bank promise to do something by certain time, it does within timeframe } & Public Bank & \multirow{2}{*}{-2.300} & $005 *$ \\
\hline & Private Bank & & $.005^{*}$ \\
\hline & Public Bank & 2346 & $003 *$ \\
\hline When customer face problem, bank is sympathetic and reassuring & Private Bank & -2.346 & $.003^{*}$ \\
\hline Bank keens its record accurately & Public Bank & 1707 & 060 \\
\hline Bank keeps its record accurately & Private Bank & -1.707 & .060 \\
\hline Responsiveness-willingness to help customers and provide prompt service & & & \\
\hline Rank tell customers when the services will be nerformed & Public Bank & 2266 & $001 *$ \\
\hline Bank tell customers when the services will be pertormed & Private Bank & -2.260 & $.001^{*}$ \\
\hline You receive nromnt service from hank's emplovees & Public Bank & -1544 & 088 \\
\hline You receive prompt service from bank's employees & Private Bank & -1.544 & .088 \\
\hline Emplowes of the bank are willing to heln cuctomerc & Public Bank & 2410 & $002 *$ \\
\hline Employees of the bank are willing to help customers & Private Bank & -2.410 & $.002^{*}$ \\
\hline Fmnlovees of the hank resnond to customer reguests & Public Bank & 2251 & $008 *$ \\
\hline Employees or the bank respond to customer requests & Private Bank & -2.251 & $.008^{*}$ \\
\hline Assurance-courteous employees who can inspire confidence & & & \\
\hline You can truct amplovees of hank & Public Bank & 428 & 480 \\
\hline You can trust empioyees or bank & Private Bank & -.428 & . 480 \\
\hline You feel safe in your transactions with hank's emplovees & Public Bank & -1244 & 065 \\
\hline You reer sare in your transactions witn bank s empioyees & Private Bank & -1.244 & . \\
\hline Employees of hank are nolite & Public Bank & -1363 & 030 \\
\hline Employees of bank are polite & Private Bank & & \\
\hline Employees get adequately sunport from hank to do their iphs well & Public Bank & 1024 & 200 \\
\hline Employees get adequately support trom bank to do their jobs well & Private Bank & -1.024 & 200 \\
\hline Empathy-personalized attention and care & & & \\
\hline Bank oive vou individual attention & Public Bank & -1056 & 133 \\
\hline Bank give you individual attention & Private Bank & -1.056 & .133 \\
\hline Fmployees of hank oive your nersonal attention & Public Bank & -1463 & 006 \\
\hline Empioyees or dank give your personal altention & Private Bank & -1.403 & . \\
\hline Fmnloyees of hank understand customer needs & Public Bank & 1461 & 007 \\
\hline Employees of bank understand customer needs & Private Bank & -1.461 & .007 \\
\hline Fmplovees of hank have your hest interest at heart & Public Bank & 2342 & $005 *$ \\
\hline Employees of bank have your best interest at heart & Private Bank & -2.342 & $.005^{*}$ \\
\hline Bank has convenient onerating hours & Public Bank & -3.108 & $001 *$ \\
\hline & Private Bank & & \\
\hline
\end{tabular}




\section{Independent t-Test}

Table no. 2 shows the correlation between the assessments of clients of public and private banks on service quality. With the assistance of an Independent t-test, the examination analyzed the critical contrast in their feelings. The estimation of t-insights and p-esteem are appeared in the table 2.

Every assertion quantifies the unmistakable measurement that is examined and dissected exclusively. The theory was planned to investigate the assertions.

Ho: There is no significant difference in customers' opinion of both banks with respect to service quality.

Ha: There is a significant difference in customers' opinion of both banks with respect to service quality.

Table 2 indicated that the outcomes discovered to be huge at five percent level for the assertions The presence of the actual offices of the bank is with regards to the kind of service gave Bank is trustworthy, when banks guarantee to accomplish something by a certain time, it does inside time period when the client face issue, a bank is thoughtful and consoling. Banks tell clients when the services will be performed. Employees of the bank are eager to help clients, react to client demands and have your wellbeing on a basic level. Bank has advantageous working hours, implies that the invalid theory was dismissed. The investigation broke down that there is a critical distinction in the assessment of public and private bank clients.

Contrasting aftereffects of clients' sentiments, it very well may be summarized that in private banks the service quality is moderately better than that of public banks. In any case, it very well may be investigated that the clients are indicating that in their bank there is lower service quality which may influence their drawn out a relationship with the bank.

In general correlation of public area bank and private area bank on service quality variable, Table No. 02 shows the general examination between the public and private area banks on service quality variable with the assistance of an Independent t-test. To check the hugeness contrast in the assessment of the clients' speculation was planned and Independent t-test was applied to establish the outcomes thereof.

Ho: There is no significant difference in the opinions of customers of public and private sector banks on service quality of banks. Ha: There is a significant difference in the opinions of customers of public and private sector banks on service quality of banks.

Table 3. Overall Comparison of Bank Customers Opinion on Service Quality Variable

\begin{tabular}{|c|c|c|c|c|c|}
\hline Type of Bank & $\mathrm{N}$ & Mean & Std. Deviation & t-statistics & $\mathrm{p}$-value \\
\hline Public Sector Bank & 120 & 2.5887 & 1.0113 & & \multirow{2}{*}{-2.376} \\
\hline $\begin{array}{c}\text { Private Sector } \\
\text { Bank }\end{array}$ & 120 & 2.8543 & 1.1104 & $000 *$ \\
\hline
\end{tabular}

Sources: Primary Data, Significant at 5 percent level

From the table no. 3 shows that the mean score of public area banks $(2.5887, \mathrm{SD}=1.0113)$ and the mean score of private area banks $(2.8543, \mathrm{SD}=1.1104)$ as the t-test was discovered huge t-esteem $=2.376, \mathrm{df}=240$, p-esteem $=0.000$. It was found from the examination that invalid speculation was dismissed. The examination means that there was a huge distinction in the assessment of clients of public area banks and private area banks on the service quality variable.

\section{Suggestions}

1. The investigation recommended that they should finish their guarantee in a specific time, the appearance of actual offices should be kept with the sort of service supplier, advise their client when precisely the service going to perform, the bank should be thoughtful and furthermore consoling their client on the off chance that they face any issue.

2. Employees ought to react to their solicitation speedily, representatives show their eagerness to help them, and banks have advantageous working hours and their wellbeing on a fundamental level.

3. The investigation uncovered that the private area bank clients indicated that their bank has better service quality when contrasting with the public area bank clients.

4. Organizations ought to underline more on client relations to persuade them with their items and services not exclusively to address their issues yet need to go further above and beyond. At the end of the day, creating and expanding closeness with clients is the main methodology to improve the client dependability.

\section{Conclusions}

The banks are not dependable and solid, banks don't have outwardly engaging offices, banks are not thoughtful and consoling in the event that they face any issues and banks additionally never complete their guarantee. Aside from this, they are not happy with bank representatives and have the assessment that they don't give brief services to them, not ready to help them, generally appear to be excessively occupied, and don't tell when service will precisely be given and performed. The banks do not give them individual consideration, not indicated their premium in necessities of the client on the most fundamental level, and furthermore don't have the foggiest idea about the requirements of their client. The clients of private banks are not accepting the brief services from their bank representatives and they likewise not offer types of assistance on an ideal opportunity to their clients. Representatives seem perfect and fashionable and they react to clients' solicitations expeditiously. Representatives are dependable and amiable to them as 
clients have a sense of security when they execute with them. Further, they advise clients when the service will perform and consistently complete their responsibility as expected.

\section{REFERENCES}

[1] Khatab, J.J., Esmaeel, E.S., Othman, B, The influence of service quality on customer satisfaction: Evidence from public sector and private sector banks in kurdistan/Iraq, International Journal of Advanced Science and Technology, Volume 28, Issue 20, 31 December 2019, Pages 865-872.

[2] Sharma, R., Mittal, A., Bagga, T., Customer satisfaction for ATM services: A comparative study of public \& private sector banks in Sahibabad, International Journal of Recent Technology and Engineering, Volume 7, Issue 6, April 2019, Pages 1562-1568.

[3] Ammara Noreen, Rabia Asif, Sabahat Nisar, Noman Qayyum, Model Building and Forecasting of Bank Credit to Public and Private Sector, Universal Journal of Accounting and Finance Vol. 5(4), pp. 73 - 77, DOI: 10.13189/ujaf.2017.050401.
[4] Choudhury, K., Service quality and customers' behavioural intentions: Class and mass banking and implications for the consumer and society, Asia Pacific Journal of Marketing and Logistics, Volume 27, Issue 5, 9 November 2015, Pages 735-757.

[5] Choudhury, K, The influence of customer-perceived service quality on customers' behavioural intentions: A study of public and private sector banks, class and mass banking and consumer policy implications, International Review on Public and Nonprofit Marketing, Volume 11, Issue 1, April 2014, Pages 47-73.

[6] Toloie-Eshlaghy, Ghafelehbashi,, Alaghebandha, M, An investigation and ranking public and private islamic banks using dimension of service quality (SERVQUAL) based on TOPSIS fuzzy technique, Applied Mathematical Sciences, Volume 5, Issue 61-64, 2011, Pages 3031-3049.

[7] Sujatha, J, Ananthanarayanan, N.R., Kannan, M. A study on the application of ICT in banking services with special reference to selected private and public banks in Kanchipuram, 2013 IEEE Conference on Information and Communication Technologies, ICT 2013, Article number 6558139, Pages 456-461.

[8] Ogilo Fredrick, Omwoyo Jeremiah, Zipporah Onsomu (2018). The Relationship between Liquidity Risk and Failure of Commercial Banks in Kenya. Universal Journal of Accounting and Finance, 6(1), 7 - 13. DOI: 10.13189/ujaf.2018.060102. 